ECONOMIC THEMES (2020) 58(4): 431-457

S sciendo

DOI 10.2478/ethemes-2020-0025

\title{
IMPACT OF DIGITALISATION ON ECONOMIC GROWTH, PRODUCTIVITY AND EMPLOYMENT
}

\author{
Milojko Arsić \\ Faculty of Economics, University of Belgrade, Serbia \\ $\triangle$ arsicm@mts.rs
}

UDC

004.9:33

\begin{abstract}
Since the industrial revolution, technological innovations have enabled rise in productivity, employment, standard of living and the total population several times. In the last 15 years productivity growth has slowed-down in the most of large economies, probably due to slow diffusion of advanced IT solutions, but also due to inadequate statistical measurement of the value of IT services and slow progress in complementary and other technologies. The acceleration of productivity growth in the future is possible to foster through larger public investment in infrastructure and fundamental research, tax incentives and subsidies attached to innovations in the private sector, as well as through promotion of entrepreneurship and the reform of education system. The development and diffusion of digitalisation and other technologies is expected to trigger a slight acceleration in productivity, while explosive growth in productivity, as predicted by some theoreticians, is not likely to happen. The net effect of digitalisation on employment will be probably negative, but it is uncertain how much will be offset by a rise in availability of goods and services and creation of new types of goods and services. Employment will depend on the speed of adjustment of education system to technological changes and labour market requirements, as well as on the possibilities for vocational education and change in qualifications. An important reserve, which may reduce a drop in employment and enhance the welfare of citizens, lies in additional reduction of the working hours. In the long run, it is expected that the world population growth is to slowdown and then become negative, which will lead to a decrease in the labour force. In that case, full employment will be attained even with the decline in the number of jobs. In case of long-term massive unemployment, there is also an option for introduction of universal basic income or other type of social benefits, in order to prevent a significant rise in economic inequality.
\end{abstract} Original scientific paper

Received:

26.10.2020

Accepted:

24.12.2020

JEL classification: B22, E24, J24, O33 


\section{Introduction}

Digitalization represents a general-purpose technology which is or can be applied in almost all economic activities - it is widely applicable in households, scientific research, public administration, military service, etc. Digitalization significantly affects economic activity, productivity and employment, and experts believe that the impact in the future will be even greater. In economic history, a relatively small number of technologies, e.g. electrical energy, has had such a wide application range in economic activities and households.

The process of digitalization had started during World War II, when the first electronic computers were constructed. The next couple of decades, their performance, such as the speed of data processing and the capacity for data storage, were increased multiple times, but until the 80 s the distribution of computers was very limited. Until that time, computers were mostly used in public administration, big companies, at universities, research centers and military service. The development of PCs, since the mid 70s of the last century, which was evident through better performance, but also through a massive drop of prices, had a great impact on the widespread usage of computers, so from the 80 s their distribution started growing in small and medium-sized enterprises and households. The next impulse of digitalization came with the rise of Internet and telecommunication, which enabled fast and cheap transfer of great quantity of data during the $90 \mathrm{~s}$.

In addition to the increase of procession speed, the possibility of storage and the transfer of data, the development of computers is evident in their ability to solve numerous complexities, as well as a broad class of problems, unlike the earlier stage of development. Computers already manage complex industrial processes, help in bringing favorable business decisions, making accurate diagnoses, solving legal matters, translating texts and speech. There are many ongoing research projects whose goal is that the computers and machines managed by them be enabled to perform a large number of tasks much faster, cheaper and effective, which were previously performed only by people. Experts estimate that in the future years and decades the artificial intelligence will, more or less, conduct various activities - administrative, accounting, auditing, stock exchanging, marketing, but also other tasks, such as managing the means of transportation, making diagnoses, and administering therapies or other medical work. Of course, it is still not certain when and if the computers and machines managed by them will only be included in the above mentioned activities or completely take them over.

The predictions of scientific and technological progress are utterly uncertain, especially the long-term ones, particularly if one compare today's forecasts with those 4-5 decades ago. On the one hand, for example, in the $60 \mathrm{~s}$, experts believed that nuclear power plants would have become the main source of energy by the end of the XX century; that people would have bases on the Moon and Mars, and that 
the humanoid robots would do all the housework at the beginning of the XXI century. On the other hand, most of the scientists did not predict a strong development and the massive usage of computers and telecommunication, the development of genetics, etc.

From the point of view of economic analysis and policy, it is important to find out how the former digitalization affected the economic growth, employment, productivity, the standard of living and economic inequality. It is not easy to easily respond to these questions, because along with digitalization occur many technical innovations, as well as changes in institutions, economic policy, international economic relationships, organization of production, etc, so it is hard to separate the impact of digitalization from the impact of other factors. It is equally important to find out how digitalization will affect economy and community in the future, and if the people will be able to find out other reliable jobs if/when computers and machines take over, whether digitalization will accelerate growth of economy and productivity, and also economic inequality. Other important questions related to this topic are also the following: how economic and social policies should look like in order to achieve certain social goals related to economic growth, employment and social (in)equality in digital environment, and more generally speaking, in the environment of technical progress.

As much the estimation of the impact of digitalization on economy and community in the past was complex and unreliable, the forecast of its impact in the future is even more uncertain. It's not easy to determine which tempo will digitalization have and which areas it will affect, in which direction and in which speed other technical innovations will occur, what institutional ${ }^{1}$, market, organizational changes will take place and how international economic relationships will develop².

The first chapter analyzes the impact of technical innovations, including digitalization, on the economic growth and productivity from the beginning of the industrial revolution until the present day. The second chapter analyzes the impact of innovations and technical progress on the volume and structure of employment. The mechanisms and the intensity of the impact of innovations on economy in the past could be useful in understanding their impact in the future. The third chapter considers the effect of digitalization on economic growth and labor market in the future. The fourth chapter analyzes possible responses of economic policies and institutions to changes in economy and community that will be created by digitalization.

\footnotetext{
${ }^{1}$ When the institutions are in question, it is essential to determine whether the changes will be directed towards the correction of liberal order or stregthening of different kinds of authoritarianism.

2 The course of global economic development will depend either on intensifying the globalization process or strenghtening of protectionism.
} 


\section{Impact of innovations on economic growth and productivity}

Technical progress that brought to the industrial revolution, and the unprecedented economic progress in the history, started in 18 century with a series of technological innovations in western countries ${ }^{3}$, and it continued spreading to other parts of the world. Technical innovations increased productivity, i.e. productivity per worker and total productivity, which enabled enormous growth of the number of people in the world, the multiple increase of the standard of living due to the increase of the quantity of product per inhabitant ${ }^{4}$ and reducing the working hours. The series of crucial innovations which set forward the industrial revolution enabled mankind to step out of the Malthusian trap, which implies that some rare innovations brought to a temporarily increase of standard, which further enabled survival rates and the increase of population. The growth of population reversed the standard to the level which existed before the existence of innovations, so the rare innovations before the industrial revolution enabled the moderate growth of population followed by stagnation and slow growth of standard in the long run.

After World War II, especially during the last few decades, digitalization has been one of the key areas of technological progress. One of the specific characteristics of digitalization is that it pervades (or has a possibility to pervade) all economic sectors and human activities. According to the influence on all forms of economic and human activities, only electrification can be compared to digitalization. Another characteristic of digitalization that makes it stand out in comparison to other technologies is that it exhibits a huge, some believe, unlimited possibility for progress and further development.

Along with digitalization, technological progress further continues in other areas such as: creating new materials in industry, construction, nuclear technology, telecommunication, nanotechnologies, biotechnologies, means of transportation, pharmacology, medical equipment, agricultural machinery etc. The influence of an innovation on productivity in one area depends on an innovation in other areas, which means that there is complementarity between them. For example, the development of self-driving cars requires complementary innovations in the areas of digitalization, radio detection and ranging, sensors, geographic maps, telecommunication, and probably a certain adjustment of roads, traffic signs, parking areas, power supply systems (instead of gas), and traffic rules. If the innovations in one area are not accompanied by the innovations in complementary areas, the effect on productivity will be lower.

\footnotetext{
3 The fundamental driving force of technical progress are probably the ideas of rationalism and enlightenment, as well as the institutional changes that emerged in a few countries.

${ }^{4}$ The model of endogenous technological progress, as the main driving force of growth of production, population and the standard of living, was developed by Kremer (1993).
} 
The most crucial economic effect of innovations is the increase of productivity and GDP per capita, and the increase of consumption i.e. the standard of living at the same time. The increase of productivity, besides the increase of consumption quantity, enables the reduction of working hours which implies the increase of leisure, and also the usefulness of consumers and social welfare ${ }^{5}$. Besides technological innovations, changes in institutions and economic policy also influence the increase of productivity, as well as changes in domestic and international economic relationships. Productivity is also influenced by market and organizational innovations which improve the efficiency of production, such as the introduction of serial and mass production, logistics development, creating new sales channels and completely new services, the development of financial instruments etc. Productivity is also influenced by workers' knowledge and skills, since more educated and better trained labor force, with identical technology, accomplishes greater productivity. Technological, market and organizational innovations, as well as the increase of human capital, affect the productivity growth, where its impact is often interdependent.

It is estimated ${ }^{6}$ that global GDP since 1700 , i.e. since the beginning of the industrial revolution until 2015, increased about 170 times, i.e. 1, 7\% annually on average. In the same period, the number of population increased 12 times, which means that GDP per capita since the beginning of the industrial revolution increased about 14 times, while the average annual growth was $0,8 \%$. Due to lack and unreliability of data on employment in the world in XVIII and XIX century, the flow of GDP per capita represents a new approximation ${ }^{7}$ of productivity flow, which means that productivity over the last 3 centuries has grown 14 times.

After World War II, economic growth started accelerating, so the cumulative growth of GDP (1950-2015) increased 12 times, 3, 9\% annually on average. In the same period, the number of world population increased approximately 3 times, while the cumulative growth of GDP per capita increased nearly 4 times which implies an average annual growth of 2, $1 \%$.

Work productivity in Western countries after World War II was increased between 3 to 5 times, while the productivity in China and Japan in the same period was increased even 14 to 15 times. Work productivity had a relatively strong growth in all observed large economies until 1990, and after that, there occurred a significant slowdown of its growth in Germany and Japan, the countries which had had the fastest productivity growth after World War II. In the period 1990-2005, work productivity accelerated growth in China and the USA, while it was slowed down in other economies. The accelaeration of productivity growth in the USA, in

5 According to standard economic theory, the usefulness of consumers depends on income/consumption and leisure, while the social welfare is attained by aggregating individual functions of usefulness.

${ }^{6}$ OUR World in Data based on Maddison Projecta data.

${ }^{7}$ It contains an implicit hypothesis that the number of employed in comparison to the number of population is almost constant. This hypothesis is reasonable for the period when the most of the labor force was engaged in agriculture, where cyclic variations of employment were negligible. 
the specified period, is frequently explained by an explosive development of IT and telecommunication (Shackleton, R. 2013), while a forceful acceleration in China was a consequence of high investments which enabled the realocation of resources from less productive sectors, regions and forms of ownership to more productive (Ding, S., 2016). After 2005, productivity growth was strongly slowed down in all observed large countries, except China.

Graph 1.

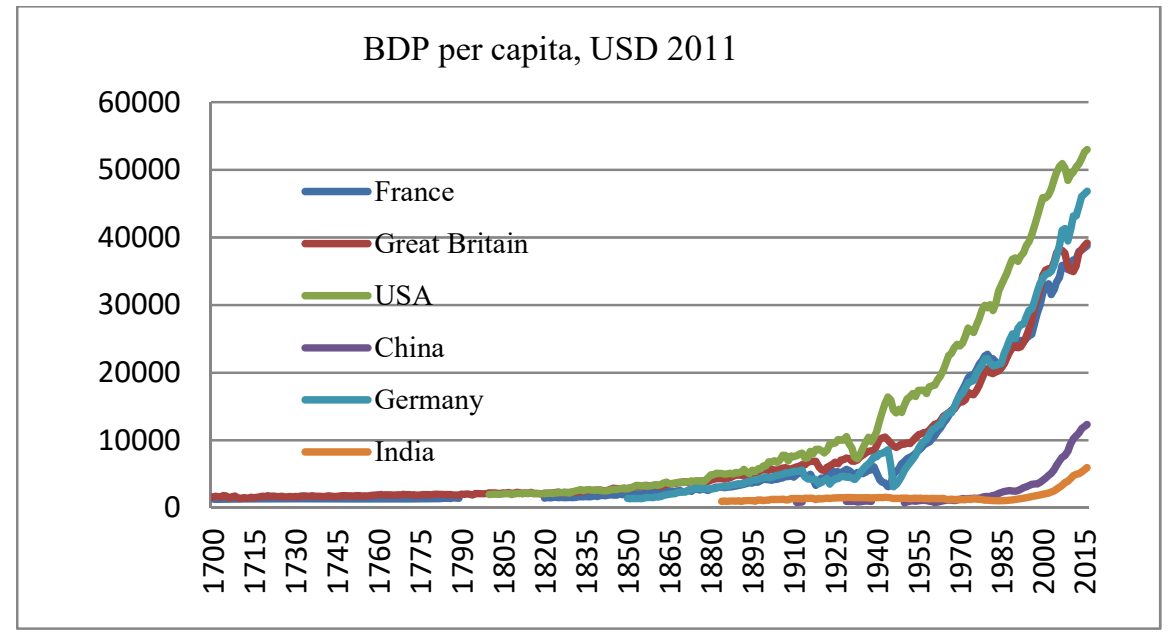

Source: Maddison project, database 2018.

Graph 2

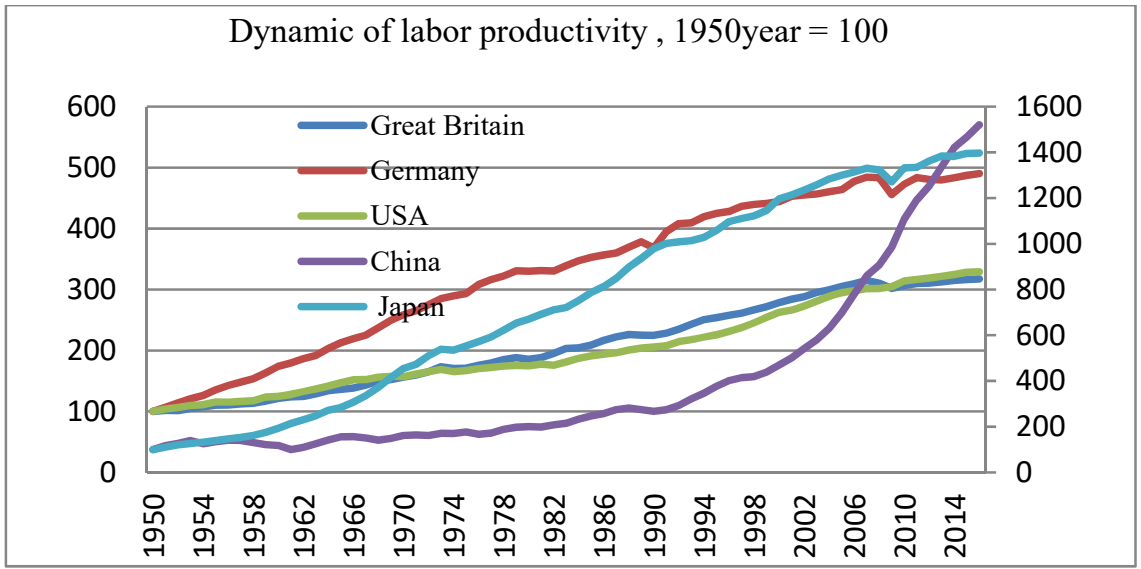

Source: Calculated based on http://www.conference-board.org Note: China and Japan are presented on the right $y$ axis. 
Therefore, the goal of numerous research programs is to determine which reasons crucially contributed to the slowdown of productivity in the last 15 years, despite the fact that a strong technical progress was accomplished in the field of digitalization in the specified period. It is estimated that the most convincing explanation of disproportion among great number of innovations, on the one hand, and the slow increase of productivity, on the other, lies in the fact that the key innovations in IT, especially in the field of machine learning and artificial intelligence, still haven't found a broad usage (Bryjolfsson and others, 2019). The delay between the creation and the mass usage of new technologies partly occurs because they still haven't attained technically and commercially satisfactory performances, while in some cases, for broader usage of innovations, complementary technologies haven't been developed yet. If this is the main reason for productivity growth slowdown, then the slowdown is only temporary, and in the future one can again expect the acceleration of productivity growth.

Table 1 Average annual productivity growth rate (\%)

\begin{tabular}{|l|r|r|r|r|}
\hline & $1950-2017$ & $1950-90$ & $1990-2005$ & $2005-2017$ \\
\hline $\begin{array}{l}\text { Great } \\
\text { Britain }\end{array}$ & 1,8 & 2,0 & 2,0 & 0,4 \\
\hline Germany & 2,4 & 3,3 & 1,6 & 0,5 \\
\hline USA & 1,8 & 1,8 & 2,4 & 1,0 \\
\hline China & 4,2 & 2,5 & 6,6 & 7,1 \\
\hline Japan & 4,0 & 5,9 & 1,9 & 0,7 \\
\hline
\end{tabular}

Source: Calculated based on http://www.conference-board.org

Besides the uneven flow of total work productivity over time, there are huge differences in the productivity flow according to economic sectors within specific countries. In the most of the countries, the fastest growing productivity occurred in the sectors which produced physical products, such as agriculture, industry and traffic, while the productivity in the service sector grew considerably slower (health care, education, administrative services, personal services, etc.). The slower productivity growth in the service sector is the consequence of the fact that the technical progress in these areas dominantly manifested through the growth of the quality of services, while the substitution of work by capital was relatively low. The productivity of physicians, teachers, administrative workers, lawyers, hairdressers, etc. has not considerably increased in the last 100 years, but the quality of services was, by all means, improved. The slower productivity growth, along with accessibility of the mentioned services, affected the growing percentage of labor force in the service sector. The existence of the unique labor market within a national economy, with great differences in the productivity growth in the sector of exchange of goods and services, reflects on the growth of relative cost of 
services in comparison to the cost of products. ${ }^{8}$ Considering the fact that a great number of services (administrative, health care, educational) is provided by the state, the growth of relative cost of services presents one of the reasons for the increase of the state's share in GDP (Baumol, W.J., 1967).

According to an alternative hypothesis, the slowdown of productivity occurs because the statistical systems depreciate the added value which creates IT (Goolsbee, A. \& P.J. Klenow, 2006, Feldstein, M., 2015). However, new empirical researches indicate that measuring errors can explain only $1 / 3$ of the productivity growth slowdown (Syverson, C., 2017). One of the possible explanations of the slowdown is that it is the effect of the excessive automatization, which means that the process of automatization is stronger and faster than it is economically efficient (Acemoglu, D. \& P. Restrepo, 2018). The reason for the excessive automatization could be more favorable tax treatment of income than capital, income than work, as well as the lower flexibility of labor market than capital market. The slower productivity growth could be the effect of the excessive scientific and development investments in automatization, and the lack of development of complementary and other technologies (Acemoglu, D. \& P. Restrepo, 2018). The consequence of that is poorly balanced technological development within which the slow development of other technologies slows down productivity growth, and economic growth at the same time. Looking for an explanation for the slow productivity growth in the field of growing economic inequality and the high concentration of offer $^{9}$ within IT sector, does not have an empirical confirmation or a convincing economic argumentation.

However, there is a widespread belief that the development of artificial intelligence would affect the productivity growth in some types of services, such as administrative, accounting, legal, etc. in one to two decades.

\footnotetext{
${ }^{8}$ The productivity growth in the activities which produce physical products (exchangeable goods) enables the growth of real earnings, without the growth of unit labor costs and their prices. The existence of unique labor market within a national economy affects the increase of salaries also in the sector of services in which the productivity growth in the past was modest, which leads to the growth of the unit labor costs, and also the relative costs of services. The faster increase of service costs in comaprison to product costs draws, as a consequence, a real currency appreciation in the countries that accomplish a strong productivity growth in the sector of exchangeable goods (Balassa, B.(1964) and Samuelson, P. A (1964).

${ }^{9}$ The greatest IT companies, such as Microsoft, Google, Facebook, Amazon, Twitter etc, have a great share in the offer of sectors they belong to.
} 


\section{Graph 3}

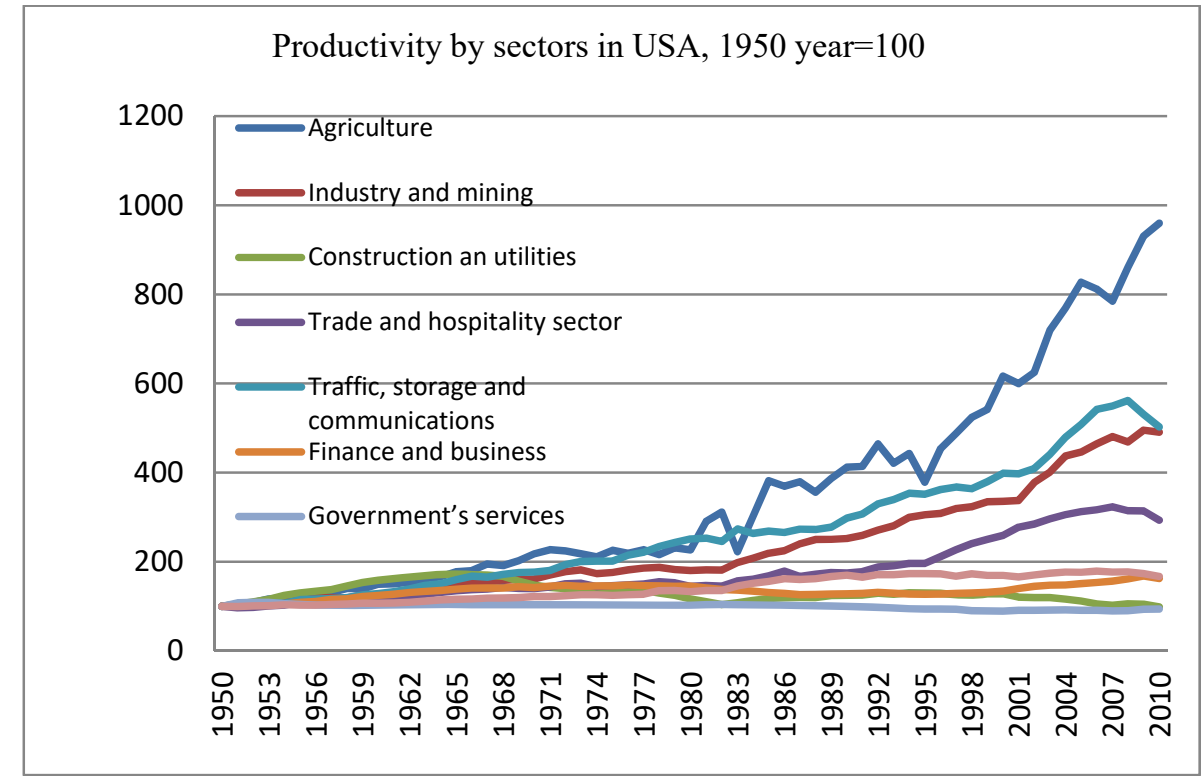

Source: Calculated based on Maddison project: Productivity 10 Sector Database

\section{Graph 4}

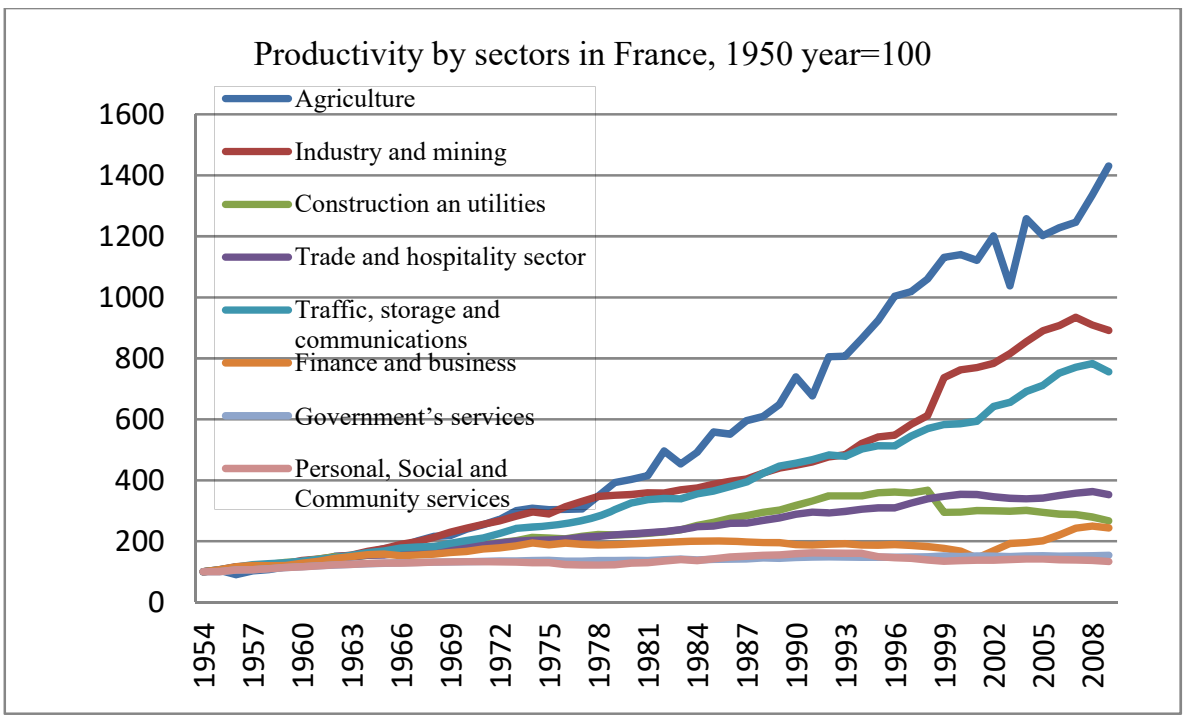

Source: Calculated based on Maddison project: Productivity 10 Sector Database 


\section{Influence of innovations on employment}

The influence of innovations on employment, the quality of workplace and the level of real income is the current topic since the beginning of the industrial revolution. The belief that innovations would close the existing workplaces brought an open resistance of workers towards the introduction of machines in production, and also an admistrative ban on the introduction of new technologies ${ }^{10}$. However, the link between innovations and employment is much complex than that. When the only effect of innovations would be pushing out the labor force, the result would be the decrease of number of employees and the drop of share of employment income in GDP. The empirical data indicate that employment at the global level, since the beginning of the industrial revolution, exhibits the trend of powerful growth, while the share of employment income in GDP, 3-4 decades ago, was stable and it amounted 2/3. Over the last few decades, the share of employment income in GDP decreases, but it is not certain to which extent it's the consequence of automatization, or other processes such as the globalization of capital market, the decrase of tax policy progress, the liberalization of labor market etc.

\section{Graph 5}

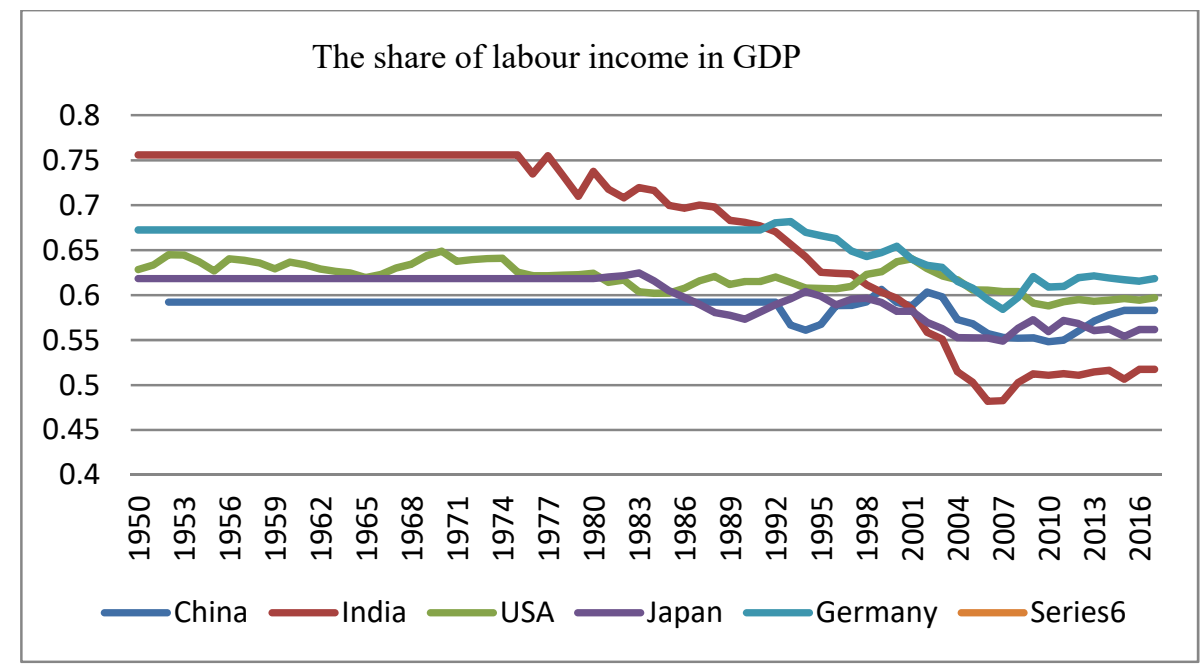

Source: Penn World Tables, version 9.1.

\footnotetext{
${ }^{10}$ The anecdote examples of banning the introduction of new technologies by Turkey, Russia etc, can be found in Asemoglu and Robinson's texts (2012), while the Luddite movement in England in XIX century presents the most famous example of workers' resistance against the introduction of machines in production.
} 
From the point of view of impact on the labor market, there are two types of technical innovations (Acemoglu, D. and P. Restrepo, 2018). One type leads to the situation that some jobs performed by people now be replaced by machines, which again leads to a drop in employment. This type includes the introduction of tractors or construction machines in production, which enables that the work with simple tools performed by a group of workers be replaced by the work of one employee. The other type of innovations, which creates new jobs that haven't existed before, such as the development of computer science and information systems ${ }^{11}$, brought to the demand of new jobs such as a computer programmer, a net administrator, a database administrator, a data analyst, a data researcher, a data security analyst, a system engineer, an IT technician, a web developer etc. Smilarly, the development of automotive industry has created a great number of jobs in car production and sales, their use and maintenance, traffic regulation, insurance, but also in the activities that are closely related to the automotive industry, suh as oil refineries, gas stations etc.

The two types of innovations cannot be clearly separated from the point of view of their impact on employment, because even in the innovations where one type of work is substituted by machines, there are introduced new jobs related to the construction and development of those machines, their production, but also related to the production of input for the machine production and usage. The production of tractors decreased the employment in agriculture sector, but, on the other hand, it contributed to the increase of employment in the tractor industry, steel mills, iron mines, rubber and electronics industry, and recently, IT sector, while the use of tractors and other agricultural machinery affected the increase of employment in extracting and processing oil, but also their maintenance.

In addition, the innovations which create new jobs also close some of the existing ones. The development of computer science brought to the creation of the great number of new jobs in the field of development and production of computers, creation and maintenance of software, telecommunication, internet etc, but it also affected the decrease of jobs in the field of mechanical computers' production, typewriters, switchboard operators, and also some admininistrative jobs.

Since the industrial revolution, the net effect of both types of innovations on employment has been considerably positive, e.g. the number of employees in Britain increased between 1855-2018 (Office of National statistics, 2019) from 11,5 million to 32,5 million, i.e. 2,8 times. Even more impressive growth in employment occurred in the USA - from 8 mil. Employed (According to Rosenbloom J., 2008) in 1850 to 150 mil. at the beginning of 2020. After World War II, despite the powerful technical progress, the number of employed in the world was increased multiple times. In the largest global economies, the increase of

${ }^{11}$ And other great innovations, such as the production and distribution of electricity, cars, planes, home appliances, industrial machines etc. triggered the creation of new jobs. 
number of workers in 2017, in comparison to 1950 was $35 \%$ in Germany and over $200 \%$ in China and India.

The innovations that close some of the existing jobs, on the other hand, create incentives for opening new job positions, based on a few factors (Acemoglu, D. i P. Restrepo, 2019). The innovations which replace people with machines affect the productivity growth. Productivity growth is, by the rule, greater than the growth of real incomes, due to which unit labor costs decrease, but also the costs of products in the activities that innovations are introduced in. The decline of product costs increases the purchasing power of households towards the products produced in innovative processes, as well as other products. An important historical example of the abovementioned process is the productivity growth in the production of agricultural and food products, which influenced the decline of their relative costs. The growing purchasing power the consumers used to purchase the greater quantity of food, but they also increased the demand for other non-existential products, such as home appliances, cars, tourist and hospitality services, culture, recreation etc, which were accessible only to a negligible number of people 100 years ago. The growth of demand for the services created new jobs, which partially compensated the employment decline in agriculture. The similar mechanism also existed in the industry sector, where the relative costs of home appliances, computers, clothes significantly dropped, which enabled the growth of demand for other products, and at the same time, the employment growth in the activites in which they are produced.

Technical innovations increase the marginal capital productivity, and also the yield per capital unit, which implies the growth for the demand of capital, which, again, implies the additional accumulation of capital (Acemoglu, D. i P. Restrepo, 2019). The growth of demand for capital increases the production of capital equipment, which triggers the opening of new job positions. The development of machine and electronic industry, as well as the industries which supply the inputs for them, during the XX century, presents the example of the specified process, which compensated the drop of employment in agriculture.

The third effect which mitigates the influence of automatization on the loss of specific jobs is deepening the automatization which, from decade to decade, increases the employees' productivity in performing the existing jobs which were partly automatized in the past (Acemoglu, D. i P. Restrepo, 2019). The productivity growth increases the demand for labor force, which, further, triggers the employment growth. The process of productivity-deepening, in jobs that were previously partly automatized, is broadly spread in different economic activities, from agriculture, over industry and construction to administrative and other service positions. 


\section{Graph 6}

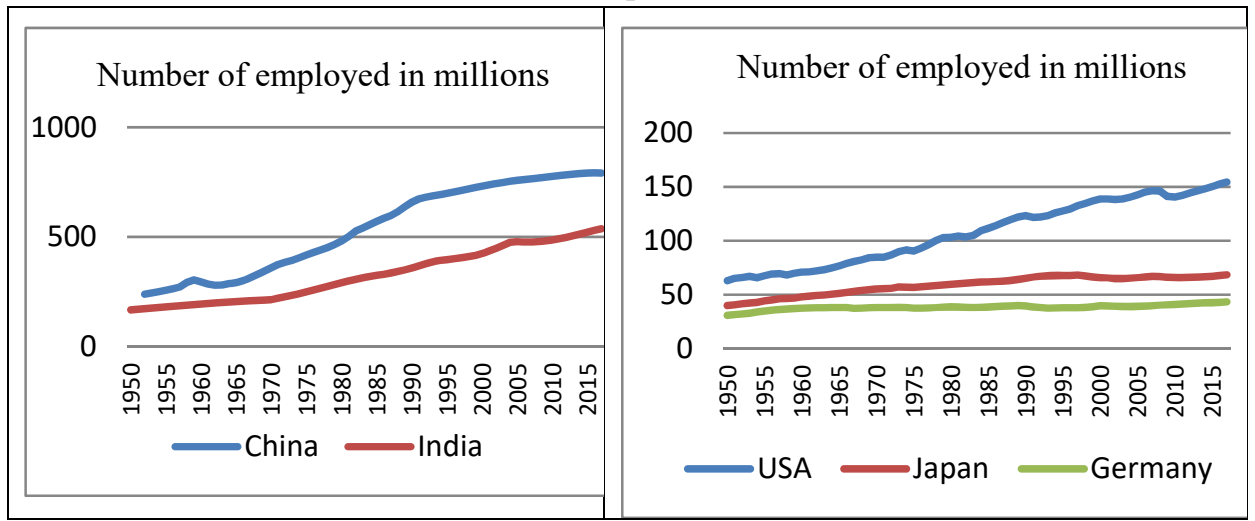

Source: Penn World Tables, version 9.1.

Since the beginning of the industrial revolution, the most significant channel of influence of innovations on employment so far has been the creation of numerous new jobs in new activities, which appeared as a result of technical progress. The development of automotive industry, electronic industry, the industry of home appliances, chemical industry, computer industry, and telecommunication etc, during XIX and XX century, had created a great number of expert, technical, engineering and other jobs. The development of industrial production, as well as the innovations in other activities, has created new jobs in the fileds of accounting, finance, management, quality control, planning, marketing, HR management etc, which didn't exist a few centuries ago. Similarly, the development of IT sector during the last few decades has created dozens of new professions, which performs a considerable percentage of labor force.

Graph 7

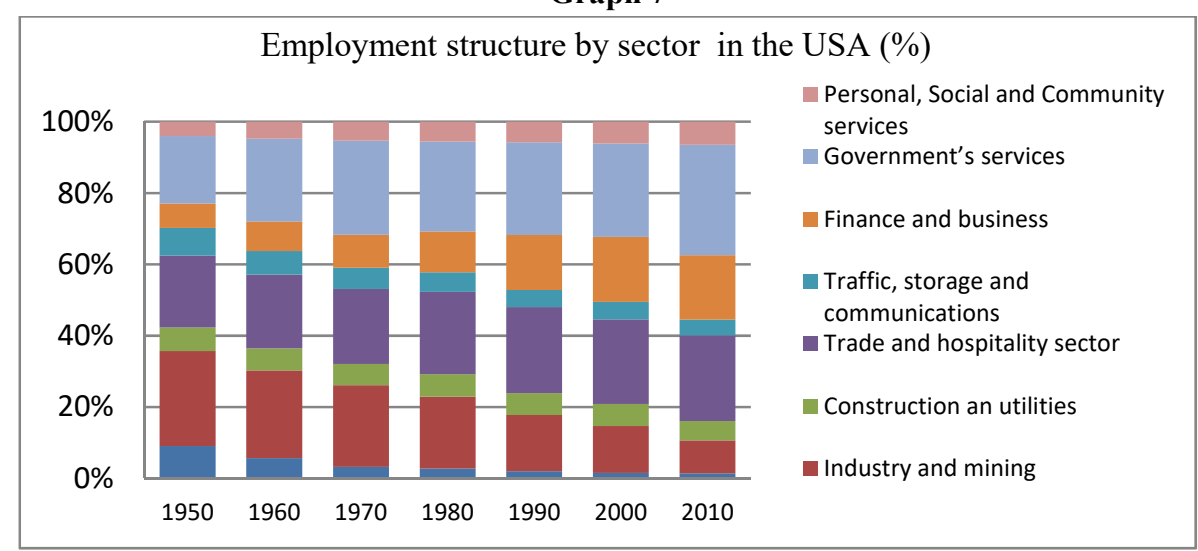

Source: Calculated based on Maddison project: Productivity 10 Sector Database 
From the beginning of the industrial revolution until the present day, technical progress has created a few times more jobs than it closed them. Technical progress enabled for the global population to grow multiple times ${ }^{12}$, but also for the largest part of labor force to be employed. Besides, technical progress has generated a significant increase of average productivity per employee, which enabled a sustainable multiple increase of real income, as well as the population standard. However, technical innovation which replaced people with machines, in certain periods brought to the growth of unemployment, the staganation of real income and the increase of inequality. The deterioration at the labor market sometimes had lasted for a couple of decades since the process of creating of new jobs was considerably slower than the closing of the old ones, which led to the increase of unemployment. In some periods, as in the example of most of the Western countries in the last 3-4 decades, newly-created jobs were less productive, which caused long-term stagnations of real income ${ }^{13}$.

\section{Graph 8}

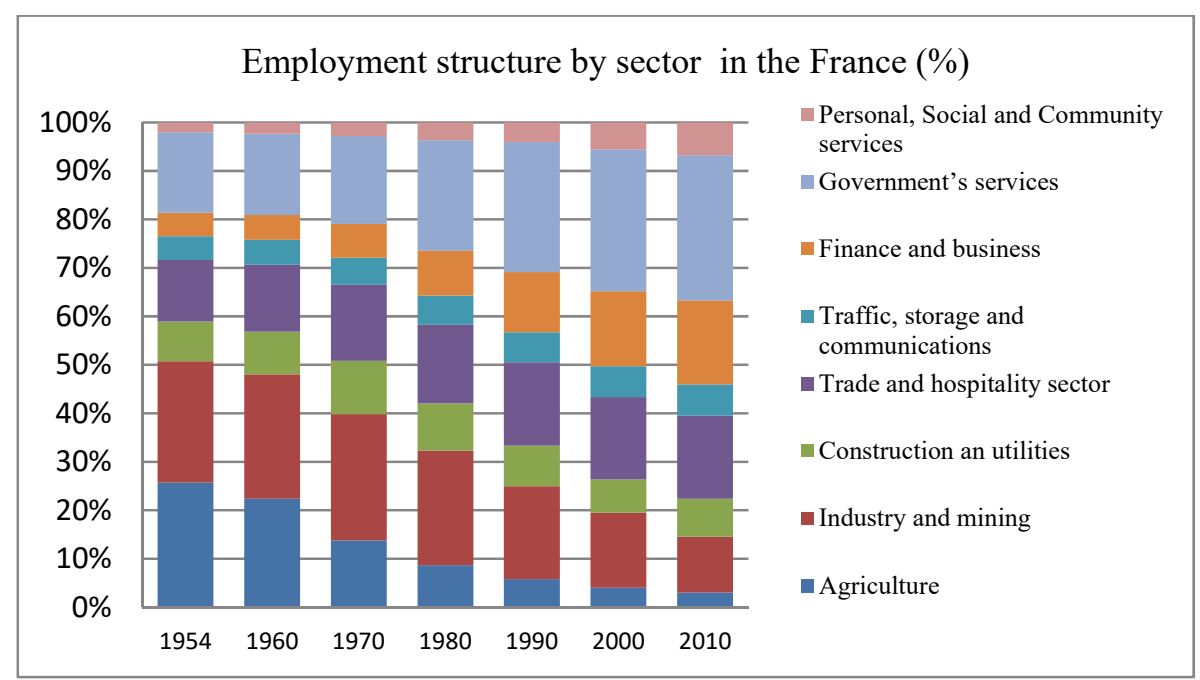

Source: Calculated based on Maddison project: Productivity 10 Sector Database

12 The connection between technical progress, population growth and the rise of standard was explained by Kremer M (1993)

13 In the example of the USA, Great Britain and other Western countries, the substitution of the quality work positions with those of lower quality is mostly an effect of their industry's transfer to abroad where the production costs, especially labor costs are much lower. The consequence of everything mentioned is that the employees who once worked at the automotive industry in the USA, for example, now work with poorly payed jobs as car detailers, food delivery workers etc. Therefore, in the USA, a few decades already, there has been accomplished a low rate of employment, but also the average real labor income stagnate, while the inequality between them grows. A good side of that process is the increase of employment and income in China, Vietnam, Brazil and other countries to which the industry from the Western countries was transferred. 


\section{Graph 9}

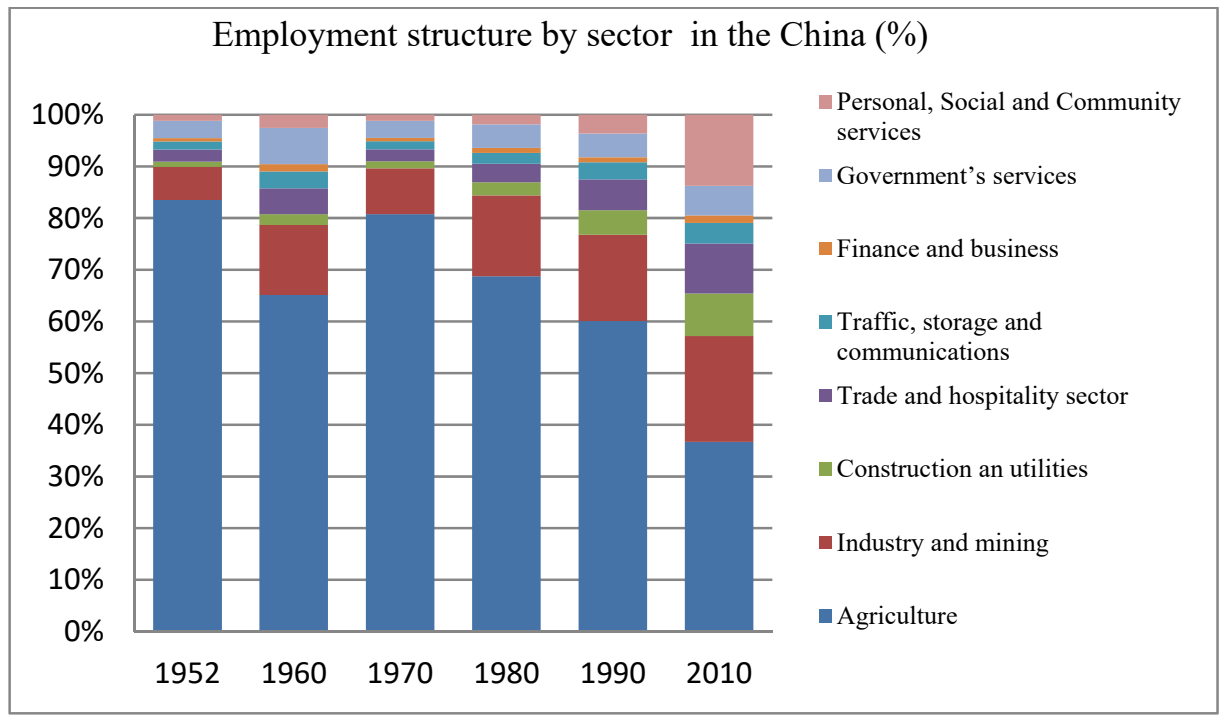

Source: Calculated based on Maddison project: Productivity 10 Sector Database

Reasons for a long-term employment or the employment of a large number of people with poorly paid jobs can be numerous. It is possible that the technical progress in the activities in which new jobs are created is slow, which means that they are not able to absorb extra employees, whose jobs were replaced by machines. Also, it is possible that the new jobs demand knowledge and skills which the labor force does not possess, so that the workers who lost their jobs can't get new, more productive ones. The crucial role in adjusting knowledge and skills to the requirements of the new job positions has the system of education, but also the labor market institutions which help the workers get a proper training to perform the new jobs. If the system of education is rigid, and if the workers don't have any options to retrain, it is likely to expect unemployment in the long run.

The cause of high long-term unemployment could be a great economic inequality and a competitive economic ambience. The great inequality implies a low demand for consumables, since the rich have a lower affinity towards consuming, so the insufficient number of people is engaged in the production of consumables. Incompetitive economic ambience implies that the rich are not sufficiently motivated to invest, which means that the production of capital goods stagnates, and, therefore, the demand for labor force is lower. Finally, the liberalization of international flows of capital could trigger a long-term high unemployment or a great share of poorly paid jobs in the total employment in certain countries, although employment, productivity and real income grow at the global level. 


\section{Influence of digitalization on economy growth and employment in the future}

Digitalization as a general-purpose technology permeats many business and private activities, and it obviously has a perspective of strong development in the future. Computer performances are still fast improving, and experts announce the appearance of quantum computers whose performance would exceed those of classical electronic computers a few times ${ }^{14}$. The improvement of these performances triggers the improvement of software, which in many complex, nonroutine activities, such as chess game, stock exchange decisions, medical diagnostics etc, exceeds human performances as in the decisions quality, or costs. In some other fields, such as the translation of texts and speech, administrative services, accounting and auditing or legal services, motor vehicles management etc, the computer performances are still weaker than human, but they are also gradually improved.

Although the strong improvement of IT in the last 15 years has been accompanied by slowing down of productivity growth, some economists, Simon H. A. (1965), Mrynjolfsson, E. i A. Mcafee (2014) believe that in the future a strong acceleration of the increase of productivity, production and the standard of living will occur as the effect of acceleration of IT progress. Such predictions are directly contrary to the pessimistic forecasts of a large number of economists and other scientists who announce a long-term slowdown or stagnation of economy due to the exhaustion of natural resources, climate changes, global overpopulation ${ }^{15}$ etc.The expectations of explosive acceleration of economic growth are based on the hypothesis that the IT development will be accelerated even more, and that it will achieve singularity in the near future ${ }^{16}$, after which the development of IT will experience an explosive growth. Such anticipation, according to which the development of IT will lead to the creation of superintelligence that would keep developing itself faster, has been present for a few decedes among IT theoreticians, but there is also a considerable number of those who dispute such possibility or postpone it for a far future.

\footnotetext{
${ }^{14}$ It is not excluded that the development of quantum computers would face the barriers in natural laws and technology, which the science is still not familiar with.

${ }^{15}$ Maltus belongs to the tradition of pessimistic forecasts for economic future of humankind. He saw an unbridgeable gap in high population growth for the increase of walefare; also, there was the Club of Rome (70s in the last century) that predicted a somber perspective of humankind due to the exhaustion of natural resources.

${ }^{16}$ The idea about the technological singularity after the development of superintelligence are attributed to von Neumann, and nowdays it is advocated by a number of IT theoreticians. The main problem with this idea is that it is not certain that computers would be capable of creating innovations, even after their considerable increase of the ability to calculate, because the process of creating innovations is quite unclear, so it is not possible to write alghorithms that would create innovations.
} 
The crucial question for economic experts is the following: Does the possible singularity in the development of IT necessarily imples the economic singularity ${ }^{17}$ ? Nordhaus (2015) claims that the singularity in IT would bring to the singularity in economy only under the specific circumstances ${ }^{18}$ that must be fulfilled either on the side of offer or demand. The conditions for the singularity on the side of demand are the following: to continue the acceleration of productivity growth in IT sector, the drop of prices of IT products has to be lower than the productivity growth, but also the elasticity of the substitution of demand between IT and non-IT sector has to be higher than one. Under these assumptions, the share of consumption of IT sector's products in the total consumption would tend towards 1 , and the increase of consumption per capita would be similar to an explosive productivity growth of IT sector. This practically means that IT inputs would be a key component in all products that households consume. Based on the statistical data on the households'consumption in the USA in the last few decades, there hasn't been even a slight indication that something like that occurred Nordhaus W.D. (2015).

Nordhaus W.D. (2015) has developed 6 tests to discover the existence of singularity signal in the production area, i.e. on the side of offer. Based on 4 tests, his findings show that on the side of offer there hasn't been any hints of economic singularity, while based on the findings of 2 tests, the results indicate that such a thing could happen in 100-120 years. Generally speaking, in order for IT sector to bring to the economic singularity, it's necessary that the very IT sector attains the singularity, but also be extremely domininant in production of all products, and also in consumption. Nordhaus concludes that the economic singularity in optimistic version, but of little possibility, could occur in one century, but it's not certain that it will ever occur.

Based on the experience in development of other general-purpose technologies over time, it seems that the most likely scenario in the years to come would be a certain increase of productivity growth rate and GDP; however, the increase wouldn't be explosive, but within the limits of historical values that have been accomplished during XX century. The initiators of productivity growth would be the development of IT, as well as the spread of its applicability, but it's also quite possible that in the future humanity would deal with natural and technological constraints for computers' development that would prevent the growth to become explosive. Productivity growth in the future can be influenced by the development and spreading of other technologies, which are being in the initial phase at the moment, such as nanotechnology, bioengineering etc $^{19}$.

17 Economic ideas at the level of speculations (e.g. that in the future an explosive development of economy would be possible) have a long history, but they also gained a theoretical grounds in the works of Simon, H.A. (1965)

${ }^{18}$ For more details see Nordhaus W.D. (2015)

${ }^{19}$ Even in the future, the development of productivity will be influenced by economic and social factors (see Chapter 2) 
When evaluating the influence of new technologies on economy and community in the future, it is necessary to consider the speed of expansion of their appliability. From the moment of invention of a new technology to the moment of its massive use in the past, many decades even centuries had to pass. Technical solutions related to production, transmission and distribution of electrical energy were discovered at the end of XIX century, but now, almost a century and a half after, there are still parts of the global population which do not have an access to electrical energy ${ }^{20}$. Many agricultural and construction (heavy) machinery has been in use for decades, which are technically more efficient in performing certain activities than people, but in many undeveloped countries, people still use human and animal labor instead of machines. A gradual distribution of certain technology makes space for creating new jobs, and sometimes for new economic activites which enable new vacancies.

The speed of distribution of a specific technology crucially depends on its cost, because the cost determines the accessibility of the technology to enterprises and households ${ }^{21}$, and also whether it is profitable to replace human labor with the new technology. A high cost of the construction of electric power system, but also a high cost of electrical energy had impact on the relatively slow distribution of one of the most universal technologies. A similar explanation was given in the case of distribution of industrial, agricultural and construction machinery, the means of transportation etc. Although it may seem that IT spread faster, according to the World Bank data from $2019^{22}$, only $50 \%$ of households in the world owned a computer, while $54 \%$ of the population had an access to internet. The mobile phone system probably represents a technology that has spread the fastest ever, where the number of customers increased from few percents at the beginning of $2000 \mathrm{~s}$ to $83 \%$ of the global population in 2019. A great speed of spreading the mobile phone system is mostly the result of low costs of construction of digital exchanges and telecommunication networks, but also the low costs of telecommunication services.

Based on economic theory, but also the historical experience, it is expected in the future that relatively cheap digital technologies would spread fast - those related to data processing, routine tasks in administration, accounting, and manual work etc. The distribution of more expensive technologies, such as various types of robots, computer-managed machines, will probably occur considerably slower. It would probably take a few decades to construct such a machine and then to mass use it in economy or households. Even now, we know about the experimental

\footnotetext{
${ }^{20}$ According to the World Bank data, about $13 \%$ of the global population in 2016 didn't have any access to electrical energy. In the USA, a few decades had to pass in order for some industries to gain access to electrical energy.

${ }^{21}$ The batteries for the storage of electrical energy already exist in households, but they are expensive, so their purchase is not profitable for the most of the households.

${ }^{22}$ This result was accomplished 70 years after the construction of the first computers, i.e. 4-5 decades after the construction of the first PCs.
} 
robots that can perform some commercial labor, e.g. waiter's work etc, but a few decades, even a few centuries wpould have to pass before they become technologically or economically superior to people, and then even more time would have to pass until the specific technologies become massively used. The robotization of craft work would be even slower, and it's possible that craftsmen will be more efficient in the near future, while the total replacement of craftspeople with machines is not likely to happen. Besides high cost, for the mass use of robots in economy and households, a possible limitiation could occur in the development of complementary technologies and in the field of technical engineering, etc.

Some scientists predict that in the near future (some say few decades, others claim 100-200 years), computers and computer-managed machines would overcome the most of the existing jobs. That's why one must ask the following question: What are the odds for computers and computer-managed machines in the near future to outperform people in all the existing jobs and perform these jobs without the control or supervision of people? The answer to this question is quite uncertain, especially if we consider the far future, but most of the presentday arguments exclude the possibility that computers and computer-managed machines would perform all the work independently, including their own production and development. Based on the historical evidence, one can expect that some jobs will be completely taken over by computers and machines, as it happened with the great number of routine operations. In case of some other activities, the level of automatization will be more profound in comparison to the present state, which means that compters and computer-managed machines will take over a numer of jobs, but people would still have a significant role in their performance. Computers will probably take over a great number of routine administrative, accounting and auditing tasks, but some of the operations in these areas related to accounting and business policy will still be performed by people. Computers will be involved in diagnostics for example, but the final diagnoses will be determined by physicians.

The competition between people and machines would probably be more complex and uncertain than it seems. Along with the improvement of performace of computers and other machines, in the future, through education and other means, people would gain new knowledge and skills which will enable them different advantages in performing activities which are not routine, as well as in performing new jobs. Other potential source for improving the competitiveness of people over computers and other machines is the improvement of their physical and mental abilities through genetics and bioengineering, so that people could be more successful than machines in completing a great number of activities. In the future, it's possible that there will emerge the innovations that will strengthen the human capabilities, such as intelligence, memory or physical abilities. Although such innovations at this moment may seem as sci-fi, nothing less probable seems the possibilty of unlimited improvement of the performance of computers, robots and other machines. 
If one assumes that in the future a great majority of the existing jobs will be completely automatized, and that people will more or less rely on computers, robots, etc. in other jobs, one may ask oneself how this situtuation will affect employment, real income and economic inequality. It is quite certain that the automatization will decrease the number of employed at the existing positions, even if indirect effects are are considered ${ }^{23}$. However, previous historical experience showes that along with the technologies that have been used to perform the jobs previously done by people, there have emerged certain innovations which created new jobs still performed by people, which are not possible to be automatized in a long period of time. So, it could be expected in the future for the new jobs to come up as a result of technical, institutional, market, organizational and other innovations. It's not possible to assume which concrete jobs we are exactly talking about, just like it wasn't possible 100 years ago to predict the jobs that exist today, related to IT, traffic, industrial, construction, and agricultural machine management.

For some jobs, even if the automatization be technologically possible, it wouldn't be economically profitable, because it will be cheaper for those jobs to still be performed by people. Finally, it is possible that the automatization of certain jobs would be ethically and politically unacceptable, even if it's technically feasible and economically profitable. It's probably not going to be morally acceptable for the court processes to be completely entrusted to computers ${ }^{24}$, but is quite possible in the future for these processes to considerably use the support of computers. Similarly, probably it wouldn't be politically acceptable for the social decisions to be entrusted to computers, but it is likely to be expected that the computers will conduct analyses which would contribute to the improvement of the quality of social decisions.

Besides creating new jobs, there is another very impotant mechanism of opening new job positions, which manifests through the accessibility of the existing goods and services, and which are unlikely to be automatized. A hundred years ago, a small percentage of people used the services in the fields of education, healthcare, tourism, hospitality, recreation, sport, entertainment, culture, and, therefore, a small number of people performed jobs which provided these services. Nowdays, in the medium and highly developed countries, a high percentage of population uses the specified services; therefore, a high percent of labor force is engaged in providing these services. Some products and services which were luxuruious in the past, with economic progress have become accessible to majority of the population. In the future, a better accessibility of these services is expected, which could bring to new vacancies. Some sevices, at the moment, which are of modest quality and used by a

${ }^{23}$ A reminder of the effects that can mitigate the decrease of employment - see Chapter 2.

${ }^{24}$ There is also a contra-argument, according to which rendering of judicial decisions to computers would bring to impartial and more righteous decisions than those brought by the people influenced by interests, emotions, individual values etc. 
small number of people ${ }^{25}$, in the future will be accessible to a majority of people, at lower prices and of better quality. It is possible that in the future the new services will enable opening of new job positions.

Another mechanism for creating new job positions is transferring the jobs which in the past had been performed within households, such as preparing food, baby sitting, caregiving for older adults, cleaning and maintaining flats and houses etc, to labor maket. This process has alredy been initiated, and its acceleration can be expected in the future.

A long-term demographic projections indicate that global population growth in the last few decades will be considerably slowed down, and that in the last decades of this century a drop in population is likely to be expected Vollset, S.E. et al. (2020). The consequence of that is the slowdown of the increase of labor force in the world, and also a decrease in the far future. This implies that the demand for the creation of new jobs in the decades to come will grow slower than in the last 3 centuries, and that in the period of the decrease of population, a full employment will be achieved with the declining number of vacancies.

Technical innovations, including digitalization, as it has occurred before, will considerably change the structure of employment, according to the activities and sectors of ownership. During the last century, technical innovations considerably decreased the employment in agriculture, while the number of the employed in the sevice sectors was significantly increased. If the expected progress in the field of artificial intelligence occurs, as a result it will have a drop in the employment in administrative, accounting and other service sectors. Considering the fact that most of the mentioned activities are performed in the public sector, it will affect the drop of employment in this sector. Of course, it is not excluded that the state in the future will take over some new functions or extend the existing ones that have already been perfomed (caregiving for older adults, social welfare, ecology, research, etc.), which can lead to an opening of new job positions in the public sector. Whether the first or the second effect will preveail depends on the total employment in the public sector - wheather it will drop or rise, and that result will further affect the direction of the total consumption of the state.

\section{Possible solutions of economic policy}

One of the important questions that experts must ask is: Will the development of IT sector require changes in economic and social institutions and economic policy in the future? An answer to this question, for now, can only be conditional, since no one is certain how IT will develop or what kind of changes in economy and community will occur. Besides IT, economy and community will also be

${ }^{25}$ An example of such services refers to various treatments for relaxation, rejuvenation, disease prevention, etc. 
influenced by technological progress in other areas, such as nanotechnologies, biotechnologies, the industry of new materials etc. In keeping with the technological changes in the future, one can expect a significant demographic changes, such as the slowdown of growth, and then the drop of global population, the aging of population, the change of population structure according to countries, religion, etc, that will imply important changes in economy and community. Enormous differences at the level of development and population growth, as well as climate changes, will encourage migrations that will lead to changes in the population structure within the individual countries.

The abovementioned, but also many other factors will influence the changes in economy and community, where the cause of change in one area can be neutralized or intensified in other areas. If a technological progress in one sector is accompanied by a progress in other sectors, the result will be the acceleration of productivity growth; otherwise, the productivity growth will be slower. Due to technical progress, productivity growth can be more or less neutralized by climate changes that will cut down the productivity in agriculture and other sectors which depend on the environment. The drop of vacancies due to IT development can be partially or fully neutralized by opening new job positions due to the development of other technologies, employing people who would take care of elderly, or a population decline, for example.

Changes in policies and institutions in the future will represent a response to the flow of basic economic variables, sucha as the growth of economic activity and productivity, the flow of employment and real income, the flow of inequality etc. Besides, the change of policies and institutions will depend on the dominating ideology in the future, i.e. on the value of life of an individual, the increase of the standard of living, economic and social inequality, the state of environment, etc. Which policies will be implemented depends on the level of independence of each individual country or some policies will be created on the supranational level.

It is possible to roughly estimate which options related to economic policy and reforms liberal demoractic societies of Western European type have to face, in which economic growth and economic equality are highly valued, if the slow productivity growth and the long-term high unemployment continues.

Governments exert a relatively wide range of policies by which they can affect the productivity growth, while the concrete measures depend on the level of development and the size of a specific country, its economy structure, fiscal position, priorities etc. The acceleration of productivity growth is possible to achieve by increasing public investments in traffic, energy, telecommunication infrastructure, as well as the environmental protection. The second possible measure is the increase of investment in fundamental scientific research, in order to 
accomplish a technological breakthrough in as many areas as possible ${ }^{26}$. The third measure is the state's tax stimulations to invest in private sector's innovations, and in case that the innovations have positive, external effects, direct subventions are justified. The fourth measure is the improvement of educational system, in order to improve the knowledge and skills of workers, but the skills of innovators. The fifth measure is the state's training and retraining programmes for more productive performance. The growth of the state's investement in infrastructure, the improvement of educational system and the retraining of employees, not only would it contribute to productivity growth, but also it would influence the growth of productivity and employment.

In order to solve the long-term high unemployment problems ${ }^{27}$, governments have plenty of new active measures available at labor market (some of them have been already implemented), such as the retraing programs, additional qualification programs, subsidies for the first jobs etc. If the changes at labor market become intensified, one can expect the increase of volume of states' provisions for these pruproses. Besides, governments can provide the adjustment of educational profiles and concrete knowledge to the market demands through education reforms, while the speed of adjustment should start growing if the technological changes accelerate. The state could directly influence the preservation of employment, if the decrease of employment at state functions be compensated with employing people on the positions such as caregiving for older adults, social protection, environmental improvement, research, etc.

The reduction of work week reperesents one of the possibly most important measures for solving the unemployment issues, but also for increasing the social welfare. Basically, that implies the continuation of the process that has lasted almost 200 years, during which the work week is halved ${ }^{28}$. The condition that the reduction does not bring to the drop of real income and the standard of living, is that the productivity growth be equal or greater than the reduction of work hours. Considering the fact that productivity grows a few percents annually, the condition that the reduction of the work week does not bring to the drop of standard is that it occurs gradually. If the trends from the second half of the last century continued regarding productivity growth, one could expect the reduction of number of work hours for $5 \%$ in the period of one decade.

\footnotetext{
${ }^{26}$ The investment in fundamental research, above all, is accessible to developed countries, especially large ones, but the results of these studies overflow other countries.

27 Developed countries, in the last few decades, did not have a problem with high rates of unemployment, but a growing number of people has worked on the poorly paid job positions, so that real income in the majority of developed countries, in the previous 3-4 decades, haven't recorded a significant growth, and in some of them it was recorded a stagnation.

${ }^{28}$ At the beginning of XIX century, a typical work day in the field of industry in Western Europe lasted for 12 hours, while the work week had six work days. Today, in all countries in Europe, the work week has five days, and the number of work hours during the week equals 35 to 40 .
} 
If the unemployment remained at the high level, even after the implementation of the abovementioned measures, it would be justified to consider the introduction of other options of universal basic income. Universal basic income, along with the maintenance of medical and educational services, would protect the citizens from the extreme poverty, but it should also provide a relatively high degree of social mobility. Since the introduction of universal income would not bring down the readiness of people to work, it would be a good thing to introduce it in the form of negative income tax as suggested by Fridman (2012). In keeping with that suggestion, citizens/households receiving the income lower than marginal income would have a right to state aid, while the citizens/households receiving the income higher than that level would pay taxes. In order to encourage people to work, the aid received by the state would be lower than the difference between the marginal income and the real income. If the unemployment rate is very high, there arises is a question: how to provide the financial means for the universal income. One of the possibilities is to introduce the tax on total capital or on those types of capital which substitute the labor force (with robots e.g).

\section{Conclusion}

The process of digitalization in the last 75 years led to enormous changes in economy and everyday life of people; according to the range of use, only the electrical energy can be compared to digital technology, while according to the potential for IT development, it exceeds all existing technologies. Over the last 15 years, the productivity growth in most of the countries was slowed down, despite the strong progress in IT field. Probable reasons for the slowdown are: relatively slow spread of innovative IT services, the absence of complementary innovations and a slow technological progress in other fields.

For now, it's likely that the spread of use and the improvement of digitalization, along with technological progress in other areas, will lead to certain acceleration of productivity growth in the future, and, at the same time, the standards similar to those from the times of prosperity in XX century. Due to natural, technologacal, economic limitations its unlikely that in the near future digitalization would bring to an explosive, self-generating economic growth.

It is almost certain that in the future a great number of the existing routine activities in the production of goods and services will be taken over by computers and other machines. On the contrary, digitalization by itself will be creating new job positions, and one can also expect technical innovations in other areas, and along with institutional and market innovations, it will be creating new jobs. However, the net effect of the mentioned changes is inevitable, i.e. it is not certain if digitalization and other innovations will lead to full employment or to a longterm mass unemployment. It is possible that digitalization and other innovations would create a relatively long-term unemployment, due to the substitution of 
specific work positions by machines, on the one hand, and the delay in creating new jobs in new activities, the incompatibility of knowledge and skills of workers with the requirements of new technologies, the slow adjustment of institutions and economic policy, on the other hand.

The response of economic policy to digitalization will depend on the way it would affect employment, productivity, economic inequality etc, along with other changes in technology, demography, and environment. In the case of long-term high unemployment, one can expect a more intensive implementation of active measures for employment, a faster adjustment of educational system, spreading of public sector's services etc. Productivity growth would enable the reduction of work week and the opening of new job positions, while the real income and the standard of living would remain undisturbed. If the unemployment remained high for a long time, even after the introduction of new measures, it would probably be necessary that a new form of universal income be introduced, along with general accessibility of healthcare and educational services.

\section{References}

Acemoglu, D. i P. Restrepo (2018) "The Race between Man and Machine: Implications of Technology for Growth, Factor Shares, and Employment", American Economic Review, 108(6): 1488-1542

Acemoglu, D. i P. Restrepo (2019) “Artificial Intelligence, Automation, and Work", Eds Agrawal A., J. Gans i A. Goldfarb The Economics of Artificial Intelligence, NBER

Acemoglu, D. i P. Restrepo (2019)" Automation and New Tasks: How Technology Displaces and Reinstates Labor", Journal of Economic Perspectives-Volume 33, Number Pages 3-30

Asemoglu, D. i Dž. Robinson (2012) “Zašto narodi propadaju - poreklo moći, prosperiteta $i$ siromaštva", Clio, Beograd

Aghion, P, B. F. Jones i C. I. Jones (2017) “Artificial Intelligence and Economic Growth", NBER Working Papers No 23928

Aum S., S. Y. T. Lee and Y. Shin (2018) "Computerizing industries and routinizing jobs: Explaining trends in aggregate productivity",

Balassa, B. (1964): The Purchasing Power Parity Doctrine: A Reappraisal. In: Journal of Political Economy, Vol. 72, pp. 584-596

Baumol, W.J., 1967. Macroeconomics of Unbalanced Growth: An Anatomy of Urban Crisis. American Economic Review 57, 415-2

Brynjolfsson, Erik and Andrew McAfee (2014). The Second Machine Age: Work, Progress, and Prosperity in a Time of Brilliant Technologies. WW Norton \& Company, New York

Brynjolfsson, E., D. Rock, and C.Sy (2019) " Artificial Intelligence and the Modern Productivity Paradox: A Clash of Expectations and Statistics”, Agrawal A., J. Gans i A. Goldfarb The Economics of Artificial Intelligence, NBER

Ding, S., A. Guariglia i R. Harris (2015) "The determinants of productivity in Chinese large and medium-sized industrial firms, 1998-2007” Journal of Productivity Analysis, Vol.45: 131-155.

Feldstein, M. (2015). “The U.S. Underestimates Growth.” Wall Street Journal, 
Fridman, M. (2012) “Kapitalizam i sloboda", Službeni glasnik, Beograd

Goolsbee, A. and P.J. Klenow, "Valuing Consumer Products by the Time Spent Using Them: An Application to the Internet," American Economic Review, 2006, 96, 108- 113.

Kremer, M. (1993) "Population Growth ana Technological Change: One Million B.C. to 1990", Quarterly Journal of Economics, 108., pp. 681-716.

Muro, M., R. Maxim i J. Whiton (2019) “Automation and Artificial Intelligence - how machines are affecting people and places", Metropolitan Policy Program at Brookings

Nordhaus W.D. (2015) „Are we Approaching an Economic Singularity? Information Technology and the Future of Economic Growth", Cowles Foundation Discussion Paper NO. 20

Office of National statistics (2019) "Long-term trends in UK employment: 1861 to 2018"

Rosenbloom, J. (2008). "The History of American Labor Market Institutions and Outcomes". EH.Net Encyclopedia, edited by Robert Whaples. March 16, 2008.

Samuelson, P A. (1964): Theoretical Notes on Trade Problems, In: Review of Economics and Statistics, 46, pp. 147-154

Simon, H. A. (1965). The Shape of Automation for Men and Management, Harper and Row, New York

Shackleton, R. (2013) "Total Factor Productivity Growth in Historical Perspectives" Congressional Budget Office, Working Paper 2013-01

Syverson, C. (2017) "Challenges to Mismeasurement Explanations for the US Productivity Slowdown,” Journal of Economic Perspectives, 31, 165-186.

Vollset, S.E, E. Goren, C-W. Yuan o dr. (2020), "Fertility, mortality, migration, and population scenarios for 195 countries and territories from 2017 to 2100: a forecasting analysis for the Global Burden of Disease Study", The Lancet

\section{UTICAJ DIGITALIZACIJE NA EKONOMSKI RAST, PRODUKTIVNOST I ZAPOSLENOST}

Apstrakt: Tehnološke inovacije su, od početka industrijske revolucije, omogućile višestruko povećanje produktivnosti rada, zaposlenosti, standarda građana i broja stanovnika. Poslednjih petnaestak godina rast produktivnosti u većini velikih zemalja je usporen, što je verovatno posledica sporog širenja primene naprednih IT rešenja, neadekvatnog statističkog obuhvata vrednosti IT usluga, ali i sporog napretka u komplementarnim i drugim tehnologijama. Ubrzanje rasta produktivnosti u budućnosti moguće je podstaći povećanjem državnih ulaganja u javnu infrastrukturu i fundamentalna naučna istraživanja, poreskim podsticajima i subvencionisanjem inovacija u privatnom sektoru, podsticanjem preduzetništva i reformom obrazovnog sistema. Razvoj i širenje digitalizacije, ali i ostalih tehnologija, verovatno će u narednim decenijama generisati umereno ubrzanje produktivnosti, ali je eksplozivni rast koji predviđaju neki teoretičari malo verovatan. Neto efekat digitalizacije na zaposlenost će verovatno biti negativan, ali nije izvesno u kojoj meri će on biti neutralisan širenjem dostupnosti postojećih i kreiranjem novih proizvoda i usluga. Zaposlenost ce zavisiti od brzine prilagođavanja obrazovnog sistema tehnološkim promenama i zahtevima tržišta, kao i od dostupnosti prekvalifikacija i dokvalifikacija. Važnu rezervu za smanjenje nezaposlenosti u budućnosti, ali i za povećanje blagostanja građana predstavlja 
dodatno skraćivanje radnog vremena. U dugom roku, usporavanje rasta stanovništva, a potom i smanjenje broja stanovnika na nivou sveta, smanjiće radnu snagu, pa će se puna zaposlenost ostvarivati pri opadajućem broju radnih mesta. U slučaju dugotrajne masovne nezaposlenosti postoji mogućnost uvođenja univerzalnog osnovnog dohotaka ili nekog drugog oblika socijalne pomoći, kako bi se sprečilo znatnije povećanje ekonomske nejednakosti.

Ključne reči: digitalizacija, produktivnost, zaposlenost, odgovori ekonomske politike

\section{Author's biography}

Milojko Arsić, PhD, is Full Professor of Public finance and Fiscal policy at University of Belgrade - Faculty of Economics. Prof Arsić is co-author of considerable number of papers, published in international and domestic journals. He is also co-autor of a few books (The Economics of Taxation: Theory ana Policy, Structural fiscal deficit and public debt dynamics in Serbia, Macroeconometric Modelling of the Economy of Serbia: Theoretical Framework and Results, Policy), and co-author of monographs (Measures to Formalize the Shadow Economy and their Effects on Economic Growth in Serbia etc. Tax policy in Serbia - looking forward, Public enterprises restructuring and institutinal constraints) and During the last two decades he participated in creation of several stabilization and reforms programs in Serbia. Vice-governor in charge of monetary policy and research departments Prof Arsić is editor inchief of the Quarterly Monitor-bulletin on macroeconomic trends, economic policies and reforms in Serbia. 